\title{
K teologické interpretaci udržitelného rozvoje
}

\author{
Václav Mezřický
}

Envigogika 2007/II/1 - Recenzované články/ Reviewed Papers

Publikováno/Published 16. 04. 2007

DOI: http://dx.doi.org/10.14712/18023061.14

\section{Abstrakt:}

Studie je pokusem o teologickou reflexi environmentálních problémů světa jak ji $\checkmark$ sekulární podobě vyjadřuje pojem udržitelného rozvoje. Text je upraveným a mírně aktualizovaným překladem př́spěvku uveřejněném ve sborníku z konzultací Evropského křestáanského ekologického sdružení (ECEN):

MEZŘICKÝ, V. (2004) A Theological Interpretation of Sustainable Development. In: Visher, L. (ed.) Listening to Creation Groaning. Report and Papers from a Consultation on Creation Theology. John Knox Series, Geneve: Centre International Réformé John Knox, str. 188-210.

\section{Klíčová slova:}

Prorocká doba, princip předběžné opatrnosti, ontologická svatost Země, dynamika technologií, udržitelný rozvoj, ekologická stopa, environmentální prostor, askeze

\section{Abstract:}

An attempt at a theological reflection on the world's environmental problems as expressed in its secular form by the term sustainable development.

A modified and slightly updated translation of a paper published as MEZŘICKÝ, V. A Theological Interpretation of Sustainable Development. In: Visher, L. (ed.) (2004) Listening to Creation Groaning. Report and Papers from a Consultation on Creation Theology. John Knox Series, Geneva: Centre International Réformé John Knox, str. 188210.

The review of the anthology as well as the full text of the memorandum Listening to Creation Groaning are included in this issue of Envigogika.

\section{Key words:}

Age of prophets, precautionary principle, ontological holiness of Earth, technological dynamism, sustainable development, ecological footprint, environmental space, asceticism 
Recenzi sborníku studií i plný text memoranda Nasloucháme úpění stvoření uvádíme $v$ tomto čísle Envigogiky.

$\mathrm{Na}$ počátku je třeba učinit několik poznámek. Předně téma je nutné uvést do souvislosti s realitami fyzického stvoření. Není možné je tedy pojednávat jen s odkazy na biblické texty a jejich interpretaci. Nejde přitom o vyčerpávající výčet statisticky doložitelných fakt, ale o vymezení tématu tak, aby bylo možné je vztáhnout ke konkrétním skutečnostem a konkrétním lidským společenstvím. Přitom materiální rámce pojednání tématu představují problémy a vztahy především euroatlantického společenství. Souvislosti s problémy společností jiných kontinentů a kultur budou zmiňovány jen okrajově.

$\mathrm{Na}$ druhé straně je třeba zdůraznit, že ani toto omezení tématu nemůže vést k umenšení jeho globálně platných horizontálních resp. systémových (geografických, sociálních, ekonomických apod.) souvislostí. Tím méně pak má redukovat všechny relevantní souvislosti vertikální, tedy ty, které směřují od člověka k Božímu majestátu a zejména naopak - od Božího majestátu k člověku.

V té souvislosti je vhodné připomenout jméno amerického přírodovědce Aldo Leopolda, který pravděpodobně jako prvý (již r. 1923) formuloval základy udržitelnosti. Aby člověk přežil, musí se, podle Leopolda, naučit myslit ve velkých ekologických souvislostech. "Myslit jako hora", slovy autorovými (Grober, 2002). I když tohoto cíle člověk nemůže $v$ úplnosti dosáhnout, je to zpưsob chápání Stvoření podle záměru jeho tvůrce. Je to důležitý krok na nikdy nekončící cestě přibližování se k obrazu, k němuž byl člověk stvořen. Je to také jediná cesta, jak překonávat nezměrnou tříšt informací, které postmoderního člověka zahlcují a banalizují tak osudově významné děje a kontury současného světa.

A konečně - reflexe současných problémů musí vycházet z vědomí diskontinuity dějinných epoch. Jde o vědomí, že současný životní styl, systém hodnot, sociální struktury a instituce mají své konkrétní historické kořeny v myšlenkových zdrojích 17. a 18. století (Descartes, Hobbes, Locke, Montesquieu, Rousseau atd.). To umožňuje rozpoznat sekulární slepou uličku, z níž máme jako nositelé své dějinnosti hledat východisko.

Stejně tak je ovšem třeba respektovat i to, co představuje kontinuitu $v$ lidském existování na Zemi. Nalézt pak pravé akcenty v Biblické zvěsti, které by se vztahovaly k naší dějinné situaci, je úkol, před nímž stojíme a který je velice nesnadný. Tyto akcenty by měly představovat nejhlubší a nejpravdivější ukazatele do budoucnosti. Teologická reflexe by přitom neměla uváznout na obecných pravdách víry. Úzkost i naděje jako existenciální stavy duše mají vždy své konkrétní dějinné souvislosti, vyžadují vždy nové tázání a nový pohled na poselství biblické zvěsti. Otázky současnosti, na něž hledáme odpověd', mají přitom význam epochální. Bultmann právem uvádí, že lidé cítí, že jsou nejen vpleteni do dějin, nýbrž i to, že jsou jim vydáni v šanc (1957). Epochální odpověd’ na epochální otázky znamená, že člověk se musí smírit s tím, že je vydáván Božímu soudu neznámých rozměrů.

\section{Jak teologicky interpretovat současnou situaci ?}

Nejméně třicet let člověk ví, že jeho pobývání na Zemi má historické pozadí, které vysílá (nejen) výstražné signály. Konkrétnost tohoto pozadí je třeba brát na vědomí při každém pokusu o reflexi existenciální situace člověka ve světě. Zopakujme, které jsou konkrétní součásti tohoto pozadí:

Předně je to globální klimatická změna. Lze o ní předpokládat, že její různé důsledky se masově projeví již v polovině tohoto století, pokud nepưsobí již dnes (zvýšený výskyt tornád na americkém kontinentu, extrémní sucha, tání ledovců aj.). Indikátorem je růst 
globální teploty z průměrných hodnot $13,48{ }^{\circ} \mathrm{C}$ v roce 1950 na $14,58{ }^{\circ} \mathrm{C}$ v roce 1998. Možné důsledky mohou mj. znamenat posun vegetačních pásem, a tedy hrozbu pro výrobu potravin, ale také zatopení ostrovních států a hustě zalidněných oblastí v místech nízkého převýšení pevniny nad hladinou oceánů.

Nedostatek vody má již dnes globální charakter. Asi jedna miliarda lidí nemá přístup k zdravotně nezávadné pitné vodě. Hladiny podzemních vod v některých zemích (např. v Indii a v Číně) v důsledku jejich intenzivního čerpání klesají o 1 až 3 metry ročně. Přitom 30 až $40 \%$ produkce potravin se právě např. v Indii pěstuje na zavodňovaných pozemcích.

Pokud jde o možnost vyrobit dostatek potravin pro rostoucí světovou populaci, odhady se liší. Podle hodnocení OSN to možné je. Nezávislí odborníci jsou však skeptičtí. Poukazují na pokles rozsahu zemědělské půdy na hlavu $v$ některých zemích $\mathrm{i} \vee \mathrm{globálním}$ průměru, a v důsledku toho i na klesající produkci v témže poměru. Nejpodstatnější ohrožení pro produkci potravin však může představovat právě klimatická změna.

Energetické zdroje. Hlavním energetickým hybatelem globalizace, pokud jde o fyzickou mobilitu, je ropa. Podle odhadů OSN nehrozí nedostatek jejích zdrojů do konce století. Ale Světová energetická rada připouští, že někdy v období let 2020-2030 se situace v zásobování ropou stane vážnou. Nezávislí odborníci (např. anglický Cambell) jsou skeptičtější a předpokládají konec globálního trhu s ropou již kolem roku 2008.

Ztráta biodiverzity je nejméně pocitóvaným nebezpečím. Až do roku 1950 tvořily porosty deštných lesů $30 \%$ povrchu pevniny. $\mathrm{V}$ polovině 90 . let se tyto lesy rozkládaly jen na 6 až $7 \%$ pevniny. Znamená to, že do 30 až 40 let mohou zmizet z povrchu planety. Ztráta biodiverzity může mít různé důsledky jak pro klimatickou rovnováhu, tak pro schopnost přírody poskytovat člověku další služby - jako jsou zdroje léků, potravin, průmyslových surovin (Mezřický, 2003).

Poslední, stále aktuálnější hrozbou zejména v zemích Organizace ekonomické spolupráce a rozvoje (OECD) je chemizace prostředí. Minimálně tři dưsledky má vstup cizorodých látek na zdraví zasažených populací: vzrůst onemocnění rakovinou, zhoršování reprodukčních schopností a masový výskyt alergických onemocnění. Někteři autoři se dokonce obávají, že může docházet ke změně mentality lidí - mj. v důsledku chemoterapie, drogových závislostí apod.(Colborn; Dumanoski; Myers, 1996; Rees, 2001).

Již ve třicátých letech ruský (tehdy sovětský) geochemik Vernardskij označil působení člověka na biosféru za geologickou sílu. Odpovídá tomu skutečnost, že člověk uvádí ročně do pohybu trojnásobek objemu hmot (důlní a stavební činností, vypouštěním emisí, ukládáním odpadů apod.) než sama př́roda. Př́rodovědci tento historický jev, jehož počátky sahají do 19. století, označují jako antropocén (Moldan, 1983; Vernardskij, 1944).

Třebaže se ekologické problémy objevovaly v horizontu lidského poznání již od druhé poloviny 50 . let a třebaže se k nim konaly již dva resp. tři světové summity, nemluvě o desítkách nejrůznějších mezinárodních konferenci, v chování člověka (lidstva) nedošlo k žádné zásadní změně. Není možné ponechat stranou, že ani církve neprošly změnou, kterou by situace vyžadovala.

Šok a rozpoznání hrozeb biosféře, tedy ohrožení předpokladů existence lidské kultury, zažívaný především v zemích euroatlantické kultury nejintenzivněji počátkem 70. let, ustoupil do pozadí před "starostmi všedního dne", nezaměstnaností na straně jedné, a konec konců "št́astně" zažívaným životem na straně druhé. Je totiž signifikantní, že podle nejnovějších průzkumů právě v nejbohatších zemích se vyskytuje největší počet "št́astných" lidí, kteří si existenci hrozeb „historického pozadí" sice uvědomují, avšak nejsou ochotni podstatně měnit svůj životní styl. Příznačně je to až $49 \%$ obyvatel USA, Kanady, Francie, Švédska, Norska, Anglie, Austrálie (WVS, 1999-2001). 
Ačkoliv jsme uprostřed krizové situace, ke změně vztahu člověka k přírodě, k životnímu prostředí, v podstatě nedochází - třebaže "voda stoupá". Soudí se ovšem, že za "krizi" Ize označovat jen to, co jako krizi člověk zakouší individuálně. C.F. von Weizsäcker označuje takový jev za subjektivní stav krize. Odlišuje ho od pojmu krize objektivní, která charakterizuje „veškeré závažné dění” (Weizsäcker, 1986). O tento přístup však musí jít, máme-li začít „myslit jako hora” (Grober, 2002).

Problém není ve skutečnosti $v$ prvé řadě $v$ historickém pozadí samém, ale $v$ souběhu chybějící věrohodné společenské reflexe a ve změněné mentalitě moderního člověka, přičemž poslední je zřejmou příčinou prvého. Vysvětlení, že člověk je jen "homo faber" nebo "homo ludens", je př́liš shovívavé, než aby mohlo být východiskem hlubšího poznání vážnosti situace člověka postmoderní doby (Jonas, 1984; Huizinga, 1958).

Daleko hlubší a situaci více odpovídající jsou myšlenky španělského filosofa José Ortegy y Gasseta. Již ve třicátých letech minulého století předjímavě napsal: "Zkoumámeli psychologické ustrojení tohoto nového typu davového člověka vzhledem $\mathrm{k}$ účinkům na veřejný život, najdeme následující: za prvé - vrozený a základní dojem, že život je snadný, vším oplývající, bez tragických omezení; každý průměrný jednotlivec má tedy v sobě pocit vlády a triumfu, který - za druhé - ho podněcuje, aby se utvrzoval v tom, čím je, a pokládal své mravní a rozumové jměníčko za dobré a úplné." (1993)

Tento přísný soud musí však být doplněn Ortega y Gassetovým tvrzením, že dokonce již člověk 30. let minulého století neviděl v tehdejším světě civilizaci; pouze ji užíval jako prírodu. A tento "svět" se k davovému člověku choval odpovídajícím zpưsobem: „....od narození ho nenabádá k žádnému omezení, nic mu nezakazuje ani ho nenutí ke zdrženlivosti, ale naopak dráždí jeho choutky, schopné v podstatě nekonečného růstu." Podle Ortegy y Gasseta to vede k tomu, že psychologii moderního člověka charakterizují dva základní rysy: volná expanze jeho životních přání, a tedy celé jeho osobnosti, a naprostý nevděk ke všemu, co umožnilo snadnost jeho života (Ortega y Gasset, 1993). Tento velmi přísný soud však platí o mentalitě většiny populací současné euroatlantické kultury a ukazuje na omezené možnosti nastolování udržitelného rozvoje.

Rakouský etolog a filozof Konrád Lorenz dokonce tvrdí, že lidské chování se v moderní či postmoderní době podobá chování symbionta, který se nemusí starat o přísun "energetických zdrojü", jež mu umožňují život. Dodává, že u člověka civilizačním procesem, který se rovná procesu domestikace zvířat, odumírá řada vlastností a schopností, jež mu jinak dríve umožňovaly žít v souladu s jeho prostředím (Lorenz, 1997).

Na druhé straně stojí 2,7 miliardy lidí, kteří v roce 1990 žili a žijí za méně než 2 USD na den. To představuje potenciál napětí mezi chudými a bohatými (World Bank, 2000).

Oslabování národního státu v souvislosti s globalizací a spolu s terorizmem vyvolávají oprávněné obavy o osud demokracií a o schopnost v době moderny vzniklých politických systémů čelit potenciálním krizím. Možný propad politických systémů do stavu anarchie a autoritativních režimů znepokojuje politické myslitele stále intenzivněji. Tak americký myslitel Kaplan se o budoucnosti demokracie vyjadřuje skepticky. Ř́ká, že pro průměrného jedince bude znamenat osobní bezpečnost více než politické hodnoty (2003). Angličtí autoři Conelly a Smith se např́klad dovolávají myšlenek amerického politického myslitele a diplomata Wiliama Ophulse: „V odpovědi na problémy identifikované Mezemi růstu (kniha manželů Meadowsových z r. 1972 - pozn. autora) a podobnými zprávami, spisovatelé jako Wiliam Ophuls, třebaže osobně je stoupencem liberálních a demokratických hodnot, předvídá objevení se environmentálně benevolentního Leviatana jako jediného politického uspořádání, které by mohlo zabránit tomu, aby se lidské společnosti vyvíjely za hranice environmentální udržitelnosti." (Connelly; Smith, 1999; Ophuls, 1997). K tomu věta z již citovaného Američana Kaplana: "Měli bychom pátrat po problémech, a ne si hovět v bláhové naději." (2003). 
Jsou teologové a křestáansky orientovaní myslitelé, kteří, majíce na zřeteli historické pozadí naší doby, s výhledem do budoucnosti hovoří o čase apokalypsy či před apokalypsou (Jonas, 1984). I když člověku není dáno, aby věděl, kdy takový čas nastane, zkušenost 20. století napovídá, že hrozba konce času pro miliony zmařených životů té doby nebyla pouhou hrozbou. Není třeba zastírat, že některé rysy biblické předpovědi apokalypsy se mohou aktualizovat tím překvapivěji, čím méně pozornosti člověk věnuje znamením, která je oznamují - a zatím předcházejí (Mt 24; L 21,5-36). Apokalyptické předpovědi Písma je třeba brát vážně, nebot' Kristus potvrzuje v této souvislosti: "....má slova nepominou..." (Mt 24,35). Znovu: konec dějin nezpochybnitelně patři do Boží kompetence. To však nevylučuje povolání člověka k odpovědnosti za nehodnou a nevěrnou správu Božího vlastnictví.

V každém případě nejvěrohodnější teologické označení lidské situace současné doby je prorocká doba. Tomu je třeba rozumět tak, že hlas církve se má stát "hlasem volajícím proti proudu". Církve musí ve jménu Božím „hrozit", ohlašovat soud - aby se ohlašované nemuselo splnit. Církve musí poukazovat na to, $v$ čem člověk podléhá duchu země a že mu podléhá. Církev by v tom a tím měla myslet "pro člověka", tedy darovat pravdu a tak zachraňovat (Tischner, 1985; Strupe, 1998).

Není bez významu, že v rámci euroatlantické kultury i v církvích je stále jen zlomek lidí, kteří si uvědomují vážnost hrozby. Se situací biblických proroků tak současnou profétii spojuje, že i proroci vnímali osamoceně a individuálně, co Weizsäcker v citované myšlence označil za "objektivní krizi", nebot́ Duch je učinil pro ni vnímavými. Stejně důležité spojení s prorockou zvěstí představuje, že objektivní krizi svého času chápali bibličtí proroci jako provinění proti Bohu i proti lidem - jak má dnešní situaci chápat současná profétie. $\mathrm{S}$ tím ovšem, že musí zahrnout celou šíri života i lidského bytí.

V první epištole Korintským vyzývá apoštol Pavel: „Nebot' kdo mluví prorocky, znamená víc než ten, kdo mluví ve vytržení..." (1K 14,5). A ve stejné kapitole jakoby dodává: „Bratři, ve svém myšlení nebud'te jako děti. Ve zlém bud'te jako nemluvňata, ale v myšlení bud'te dospělí." (1K 14,20). Výstrahy proroctví, které jsou sdělením Božím, volají po odpovědi. Vlastně ji dávají další verše kapitoly: "Budou-li všichni mluvit prorocky a přijde tam člověk nevěrící nebo nezasvěcený, bude vším, co slyší, souzen a usvědčován, vyjdou najevo věci skryté $v$ jeho srdci, takže padne na kolena a pokoří se před Bohem a vyzná: ,Vskutku je mezi vámi Bůh! '" (1K 14, 24-25). Jen v takové souvislosti může být křestáanský soud o př́tomnosti relevantní pro druhé. Je totiž výsledkem pozorného naslouchání hlasu Stvořitele. Otázka ovšem zní, zda postmoderní člověk je ještě schopen vnímat takto prostředkované poselství.

\section{Jak dnes rozumíme úloze lidských bytostí v Božím stvoření.}

Odpověd' na otázku Ize mezi lidmi víry vztáhnout jen k těm, kdo jsou prorocky vědoucí. Nebot' jen takoví lidé - i mezi lidmi nevěřícími - chápou rozdíl stavu stvoření před tím, než nad ním člověk získal masovou převahu, a stavem dnešním.

Symbolicky tuto převahu vyjadřuje ničení biologických druhů vinou člověka. Na zemi je podle systematických biologů mezi 5-100 miliony druhů. Jejich úbytek se děje rychlostí zániku jednoho druhu za den až jednoho druhu za hodinu. Za 50 let tak zcela zmizí 33 až $50 \%$ druhů. Přirozená extinkce druhů však nikdy nepřesáhla v dlouhodobém průměru víc než $10 \%$ druhů za milión let (Braniš, 2001).

Země je výlučným Božím vlastnictvím. Člověk to původně uznal. V Žalmu 24,1 čteme: "Hospodinova je země se vším, co je na ní, svět, i ti, kdo na něm sídlí." Ústy samého Stvořitele to vyjadřuje kniha Leviticus: "Země nesmí být prodávána bez práva na zpětnou koupi, nebot' země je má. Vy jste u mne jen hosté a přistěhovalci." (Lv 25,23 , $1 \mathrm{~Pa} 29,15,1 \mathrm{P}(\mathrm{t}), 2,11)$. 
Pro interpretaci takového vztahu ke stvoření Ize použít terminologii práva. Jistěže bez př́mé souvislosti s biblickou zvěstí, nicméně s užitečnou přesností, vyjadřuje normativně vztah člověka k Božímu stvoření římské právo institutem požívacího práva usus fructus. Je to právo užívat cizí věc (latinsky "uti") a těžit z ní plody. Přitom byl poživatel povinen věc užívat a těžit z ní plody jen tak, jak to činil dobrý hospodář (jako dobrý otec rodiny - bonus pater familias). Musil proto také např́klad část vytěžených plodů vynakládat na udržení věci $v$ původním nezměněném stavu (kupříkladu doplňovat stádo do stále stejného počtu). Byl také oprávněn těžit jen takové plody, které bylo možné považovat za pravidelný výnos. Poživatel tedy nesměl pưsobit na věc tak, aby změnil její podstatu. K zajištění toho, že poživatel nezmění podstatu věci, mohl vlastník na poživateli požadovat, dříve než mu věc odevzdal, zvláštní slib - kauci (cautio usufructaria), kterým se uživatel zavazoval, že bude věc rádně užívat a že věc po ukončení požívacího práva vlastníkovi vrátí; pro př́pad nesplnění této povinnosti se zavazoval k náhradě škody (Kincl, 1990).

Historické pozadí a moc člověka nad přírodou jsou důkazem, že biblickou zvěst o stvoření je třeba vidět také v její kulturně dějinné souvislosti a nepromítat do Písma převládající přístupy dnešní doby. Konkrétní biblická představa „.... at lidé panují [...] nad celou zemí...", jak je vyjádřena např. v Genesis 1,26 a podobně v Genesis 1,28: „...panujte nad mořskými rybami, nad nebeským ptactvem, nade vším živým, co se na zemi hýbe,..." pochází z jiné lidské situace, z doby, kdy člověk byl ohrožen přírodou (Šrobár, 2002).

Úkolem člověka není v této situaci primárně pečovat o přírodu a životní prostředí, ale chránit je. Rozsah vážnosti hrozeb, vyplývajících z historického pozadí, vyžaduje řídit se dokonce přísnějším požadavkem než je prevence, kdy člověk již ví, jaké dưsledky může způsobit. Takový požadavek představuje pro environmentální politiku - a pro novou etiku in spe - princip předběžné opatrnosti.

Ten znamená, že Ize-li vzhledem ke všem okolnostem, např. na základě srovnání s analogickými situacemi či procesy apod. předpokládat, že hrozí nebezpečí nevratného nebo závažného poškození životního prostředí, nesmí být pochybnosti, že k takovému poškození skutečně dojde, důvodem pro odklad opatření, jež mají poškození zabránit. Tedy je třeba učinit veškerá opatření, aby se zabránilo možným negativním důsledkům určité činnosti, ačkoliv není vždy k dispozici dostatek přesných a nepochybných údajů, dokazujících, že taková činnost negativní důsledky pro životní prostředí mít skutečně bude. Extrémní a přitom spíše častější by měl být případ, kdy by se taková riskantní činnost vůbec neuskutečňovala (Kružíková, 1997).

Není ovšem žádné podobné vodítko pro omezení spotřeby zdrojů, které jsou v dané chvíli pro člověka dosažitelné (např. tak omezený zdroj jako je ropa). Přitom má-li vzniknout alternativní kultura proti technokratické spotřební společnosti, musí jít o skromnost či askezi masově založenou právě na omezení spotřeby vůbec - a tím spotřeby všech zdrojů, obnovitelných i neobnovitelných (Weizsäcker, 1981).

Poznání krizovosti nastoluje otázku povahy a motivů odpovědnosti. Ve světle biblické zvěsti jde v nově poznávaných souvislostech o odpovědnost za celek stvoření - za člověka i za všechen ostatní život. Plná odpovědnost ovšem může vzniknout jen u dospělého člověka, tedy u toho, kdo si je vědom krizovosti situace, v níž se ocitl. Prorokovat mưže jen člověk dospělý, který si je vědom své odpovědnosti. "Jíst ze stromu poznání" pak představuje zřejmě nikdy nekončící úkol, který $v$ tomto čase dává člověku příležitost poznat vưli Boží, spočívající v povinnosti nalézt nový vztah k hodnotě stvoření.

Počátek nové etiky, která má vyznačovat tuto cestu, je v objevení nové podoby hř́chu (Keller, 2000). Od určitého okamžiku moderních sekulárních dějin existují nejen hříchy proti Bohu a hříchy proti bližním, ale i hříchy proti ne-lidskému stvoření, proti totalitě života. Tyto tři hříchy souvisejí. Ekologický hřích proti životu na zemi, ne-lidskému stvoření je zároveň hříchem proti Bohu, kterému země patří. A zároveň je to hřích proti 
bližnímu, a to včetně budoucích generací, kterým tímto hříchem odnímá podmínky pro život žitý ve stejné důstojnosti jakou požívá sám.

Katolická teologie hovoří o ontologické svatosti Země: „....bud' vůle Tvá na nebi i na zemi..." Člověk by měl chápat, že Země je sice jen nedokonalou reflexí, ale přece jen reflexí nebeského ráje. Nejen člověk byl stvořen k obrazu Božímu, ale i Země byla stvořena k nějakému obrazu. Katolický teolog domýšlí, že člověk je "korunou Božího stvoření" mezi živočichy, Země je pak korunou Božího stvoření mezi planetami galaxie (Kišš, 2002). Odtud někteří teologové hovoří dokonce o "paradeizaci” Země (Szölös, 2001).

Není ovšem snadné, kromě citovaného Žalmu 24,1, z jednotlivých výroků písma odvodit, jaký má být autenticky biblický poměr mezi člověkem a stvořením. Pojmy „správcovství a "pastýřství" mají př́liš odlišné kontexty, než aby bylo možné je př́ímočaře použít jako výklad tohoto vztahu. Základní závěr je, že Bible žádný návod upravující přímo a zřetelně vztah člověka ke stvoření nepodává. Úvodním úkolem nové etiky je proto záměrné vytvoření představy o formách zkázy. Tomu je na počátku třeba naslouchat více než proroctví zdaru. Je to cesta, jak se vyhnout apokalyptickým vyhlídkám.

Do hry se ovšem $v$ moderní technologické společnosti dostává fenomén doslova démonické síly. Je to vpravdě dynamika technologie samé, která se stává samočinnou hybnou silou. Jejím prostřednictvím se vývoj stává nejen neodvratný, ale je i poháněn kupředu a představuje přání a vưli jednajících lidí. Sít infrastrukturálních systémů - a jejich kolapsy, např. $v$ energetice - je $v$ této souvislosti nejen symbolem této překážky uskutečňování udržitelného rozvoje. Jde o fenomény, které často jen podtrhují komplexitu a netransparentnost sociálních vazeb společností současné euroatlantické kultury (Bystřický; Mucha, 2002).

Hans Jonas vyslovuje $v$ souvislosti s požadavkem na vznik nové etiky (dalekosáhlé odpovědnosti) požadavek nového druhu pokory - nikoli kvůli malosti, nýbrž kvůli př́lišné velikosti lidské moci. A dodává, co se zvláště musí dotknout euroatlantických společností, že při náročnosti obětí, vyplývajících z etiky přežití, se prostá ochrana předpokladú existence lidstva ve vyhovujícím prírodním prostředí může stát nejproblematičtěším aspektem této etiky. O co však podle Jonase jde, není zajistit trvalou podobu lidství či ji vytvořit, nýbrž v prvé řadě udržet otevřený horizont možností. To znamená nově poskytovat lidské podstatě její šance (1984). Zřetelněji vyjádřeno: změna spotřebních preferencí a vzorcú konzumní společnosti, diktovaná hodnotami udržitelnosti, znamená nutně snížení životní úrovně podle současných měřítek. To se neobejde bez přehodnocování platných sekulárních představ o lidské důstojnosti. Co přitom zůstává nepřekročitelnou hranicí pro člověka křestáanské víry je, že člověk byl stvořen k obrazu Božímu a je Boží tvor a tedy Bohu odpovědný tvor.

\section{Jak se chováme k nebezpečí, které se již objevilo ?}

Smysl odpovědi na tuto otázku je $v$ popisu reakcí a opatření prijímaných na sekulární úrovni, a zde zejména na úrovni vlád, mezinárodních organizací a na úrovni nevládních organizací.

Předně se na sekulární úrovni pokládá za metodologicky jediné možné východisko řešení ekologických problémů tržní mechanismus a podmiňování nezbytných změn aktivitami ekonomickými a sociálními. Etická stránka věci zůstává zcela stranou. Téměř Ize ř́ci, že tváří v tvář ekologické výzvě jsou všechny navrhované koncepty eticky, a tím fakticky bezzubé, formální - a nevěrohodné.

Na světové úrovni zůstává stále signifikantní miléniová Zpráva Generálního tajemníka Spojených národů Kofi Annana "My lidé" pro členské země organizace. Bez ohledu na změny ve významu a postavení organizace po 11. záŕí 2001 a zejména po válce v Iráku v roce 2003, jsou údaje ve zprávě obsažené stále relevantní (2000). 
Slovy Generálního tajemníka samého: "Zatímco mnozí z nás se těší lepší životní úrovni než kdysi, mnozí jiní zưstávají zoufale chudí. Téměř polovina světové populace stále musí vyžít z méně než 2 USD na den. Přibližně 1,2 miliardy lidí - 500 miliónů v Jižní Asii a 300 miliónů v Africe - žije za méně než 1 USD. Lidé žijící na jih od Sahary jsou téměř stejně chudí jako byli před dvaceti lety. Takový druh deprivace vyvolává utrpení, pocit bezmoci, zoufalství a nedostatek základní svobody - což všechno naopak prodlužuje chudobu. Z celkových 3 miliard práce schopných je 140 milionů zcela nezaměstnaných a čtvrtina až třetina je zaměstnána jen částečně.

Rovněž znepokojivé jsou trvající rozdíly v příjmech v minulém desítiletí. Globálně 1 miliarda lidí žijící v rozvinutých zemích získává $60 \%$ světových př́jmů, zatímco 3,5 miliardy lidí v zemích s nízkými př́jmy získává méně než 20 \%. Mnoho zemí zažívá rostoucí vnitřní rozdíly. V rozvojovém světě příjmové rozdíly jsou největší v Latinské Americe, hned na druhém místě je subsaharská Afrika." (Annan, 2000).

V největším průzkumu veřejného mínění, který byl kdy proveden, 57000 dospělých v 60 zemích vyjádřilo své názory na životní prostředí. Jen v 5 zemích ze 60 byla většina spokojená s vládním úsilím v této věci; lidé v rozvojových zemích patřili k nejkritičtějším.

Slovy generálního tajemníka Kofi Annana samého: „Výzvy udržitelnosti zkrátka přesahují velikost našich odpovědí - kterých je příliš málo, jsou malé a přicházejí pozdě." (2000). Doporučil proto některá opatření, jež by se měla přijmout na globální úrovni, aby se rozvinula nová etika globálního řízení.

1. Rozsáhlé úsilí je třeba vyvinout k zajištění veřejného vzdělávání. Reálné porozumění výzvám, kterým lidé čelí, je alarmujícím způsobem nízké.

2. Environmentální záležitosti se musí stát součástí politických rozhodovacích procesů.

3. Jen vlády mohou vytvářet a prosazovat environmentální regulaci a vyvíjet víc environmentálně príznivých tržních podnětů.

4. Je vyloučeno rozvíjet účinnou environmentální politiku, pokud se nezakládá na zdravých vědeckých informacích... Zejména dosud neexistovalo komplexní globální hodnocení velkých světových ekosystémů. (Annan, 2000).

Tyto závěry potvrzují co bylo výsledným hodnocením po Světové konferenci o životním prostredí a rozvoji v Riu de Janeiro $v$ roce 1992 (UN Conference on Environment and Development, dále jen UNCED). Na obou hodnotících summitech po 5 a po 10 letech po UNCEDu se konstatovalo, že nedošlo k žádným podstatným změnám k lepšímu ve stavu chudoby a životního prostředí v globálním měřítku.

Environmentální politika Evropského společenství se řídí především Akčními programy. Od roku 1973 jich bylo přijato již 6. Teprve 5. akční program z roku 1992 byl založen na principu udržitelného rozvoje. Tento pojem v terminologii Evropského společenství však znamená podle programu „...trvalý ekonomický a sociální rozvoj, který nepoškozuje životní prostředí a přírodní zdroje." Poslední Akční program se zaměřuje na čtyři hlavní problémové oblasti, a to na změnu klimatu, na ochranu př́rody a biodiverzity, na ochranu zdraví člověka, udržitelné využívání přírodních zdrojü a nakládání s odpady (Europa - Publications Office, 2007).

V roce 2001 Evropské společenství přijalo Strategii udržitelného rozvoje. Je to rovněž programový dokument bez stanoveného časového horizontu platnosti. Prioritami strategie jsou většinou velmi nekonkrétní deklarace, týkající se změn klimatu, dopravy, lidského zdraví a prrírodních zdrojů. Příznačně se prohlašuje, že „Kjótský protokol, kterým se má omezit produkce skleníkových plynů v rozvinutých průmyslových zemích, musí vstoupit $v$ platnost $v$ roce 2002. To se dosud ovšem nestalo - a není podstatné, že pro 
odpor Spojených států. I při stanovování opatření, týkajících se ostatních priorit, jde o mlhavá a vágní prohlášení. Tak např. v dopravě se má „podporovat využívání vưči životnímu prostředí vlídných způsobů dopravy a plné zakalkulování sociálních a environmentálních nákladů." (COM, 1999)

Podobně jako $v$ rozvojových zemích podle průzkumů veřejného mínění postupně rostou i mezi obyvateli EU obavy ze stavu životního prostředí. Podle jednoho z takových průzkumů, provedeného $v$ rámci Unie Evropskou komisí v roce 1999 v 15 členských zemích, 7 z 10 dotázaných soudilo, že ochrana životního prostředí je „....naléhavý a důležitý problém...". Více než polovina dotázaných uvedla, že se nyní více zajímají o problematiku životního prostředí než před pěti lety.

Všeobecně řečeno, Evropané byli v té době znepokojeni zejména ekologickými problémy globálního charakteru. Ničení ozónové vrstvy, mizení deštných pralesů a globální oteplování pokládali za závažnější, než problémy na národní a místní úrovni. Nadpoloviční většina respondentů uvedla, že pro zastavení zhoršování životního prostředí jsou nezbytné změny životního stylu a vyslovila ochotu platit více za výrobky šetrnější k životnímu prostředí.

Je zajímavé srovnat tyto výsledky s průzkumem, který byl proveden v roce 2002. Podle jeho výsledků:

- vzhledem k současnému stavu životního prostředí $45 \%$ respondentů zastávalo optimistický názor, že „...zhoršování životního prostředí Ize zastavit změnou životního stylu", zatímco $44 \%$ respondentů bylo pesimistických a vyslovilo přesvědčení, že „...lidské aktivity vedly již k nenapravitelným škodám na životním prostředí";

- problémy spojené s bezpečností průmyslového provozu znepokojují Evropany nejvíce. Ale i starší záležitosti (ovzduší, voda atd.) se nadále pokládají za důležité;

- polovina dotázaných byla přesvědčena, že mohou působit pozitivně na životní prostředí svými aktivitami, zatímco druhá polovina takové mínění nezastávala. Nicméně převážná většina byla ochotna "něco udělat", za předpokladu, že „...také ostatní vyvinou nějaké úsilí";

pokud jde o životní prostředí, Evropané vkládají svou důvěru především ve "sdruženi ochrany životního prostředí" a ve "vědce". Aktivity podnikání se ocitají na konci stupnice důvěry.

Závěry Evropské komise jsou, že „...v podstatě je nutná změna ve způsobu chápání ekonomických, sociálních a environmentálních cílů, aby se propojovaly a společně přispívaly k udržitelnosti" (EORG, 2002).

Nicméně environmentální teoretici vypracovali metody, které poskytují poměrně striktní, přesnou směrnici, jak zjistit, o kolik naše spotřeba překračuje nosnou kapacitu prostředí, v němž žijí jednotlivé společnosti. Zároveň jiná metoda se pokouší vymezit, do jaké míry mưžeme životní prostředí zatížit spotřebou a využíváním. V oblasti ekologických věd jsou to základní metody, jak stanovit podmínky udržitelnosti.

První metodou je metoda ekologické stopy. Umožňuje určit spotřebu zdrojů a požadavky na asimilaci odpadů konkrétního lidského společenství nebo hospodářství (tj. komunity, společnosti apod.) ve vztahu k odpovídající rozloze produktivní půdy. Vypočítává se jako spotřeba produktivní půdy na hlavu. Typické otázky, které můžeme takto klást, jsou: „Jak závisí předmětná populace na dovozu zdrojů ,odjinud' a na globální kapacitě asimilace odpadů?" a „Bude produktivita přírody uspokojovat zvyšující se materiální očekávání rostoucích lidských populací?" 
Spotřeba na hlavu se vyjadřuje v plošných jednotkách, tj. v hektarech. Většina průmyslových zemí vykazuje značný ekologický deficit. Tak kupř́kladu Rakousko překračuje svou kapacitu produktivní země o 2,15 ha na obyvatele, tj. o $250 \%$, Belgie o 2,8 ha, tj. o $1400 \%$, Holandsko o 2,85 ha, tj. o 1900 \%, Švýcarsko o 2,56 ha, tj. o $580 \%$. Z dalších zemí je vhodné uvést země nejlidnatější. Tak ekologický deficit Indie činí 0,5 ha, Číny 0,8 ha. Roli zde hraje (zatím) nízká spotřeba v obou zemích, nicméně deficit (perspektivně rostoucí) způsobuje zejména import energetických zdrojů, investic a potravin.

Druhá je metoda environmentálního prostoru. Odvozuje se od ekologické stopy. Je to maximum množství přírodních zdrojů, které člověk (lidstvo) může využívat udržitelným zpưsobem, aniž by přitom docházelo k překračování únosné kapacity území. Jinými slovy: předpokládá se, že zachování přírodního základu života je přirozeným předpokladem udržitelnosti života společnosti. Environmentální prostor pak vymezuje rámec možných aktivit, v jejichž rámci lidé mohou využívat životní prostředí (Wackernagel; Rees, 1995; Mezřický 2000).

Z metody ekologické stopy a environmentálního prostoru vycházejí nevládní organizace, které jako první zpracovávaly návrhy strategií udržitelného rozvoje. Tyto strategie zahrnují obvykle všechny dimenze udržitelnosti, tj. vedle environmentální, která tvoří její páteř, i dimenzi ekonomickou, sociální, politickou - a v omezené míře i etickou. Původně takové strategie zpracovávaly environmentální nevládní organizace v Německu, Rakousku, Švýcarsku, Holandsku. Strategie založené na systému indikátorů stanoví, o kolik bude např. třeba redukovat emise skleníkových plynů, spotřebu surovin, snižování záborů půdy atd. k dosažení rovnováhy mezi spotřebou a udržitelnou zátěží.. (WI, 1995; Kosz, 1994).

Organizace pro ekonomickou spolupráci a rozvoj (OECD) zpracovala analytický podklad, který především upozorňuje na kritická překročení únosné kapacity území jednotlivými lidskými aktivitami v zemích organizace (OECD, 2001). Do roku 2004 nakonec strategie udržitelného rozvoje přijaly všechny členské země EU (Mezřický, 2005, s. 152, pozn. 112).

\section{Co teologicky znamená, hovoříme-li o „udržitelnosti"?}

Nejdříve co je udržitelnost, udržitelný rozvoj. Oficiální definice zní: „Udržitelný rozvoj je takový způsob rozvoje, který uspokojuje potřeby př́tomnosti, aniž by oslaboval možnosti budoucích generací naplňovat jejich vlastní potřeby." (Světová komise pro životní prostředí a rozvoj, 1991, s. 47).

Nějaký přímý návod, jak zachovávat udržitelnost, a vysvětlení co udržitelnost je ve vztahu ke stvoření, Bible neobsahuje. Avšak etický základ udržitelnosti plyne z biblického základu, který představuje posvátnost života, vytvořeného Stvořitelem. Jeho vůle, aby život byl, je vưlí aby také trval - do skonání věků, které rovněž určuje jeho vůle. Podle Gn. 1,11: "Bůh také řekl: ,Zazelenej se země zelení...". Je tu oslovena země, která má zeleň vydat. Podle Gn 1,12: "A stalo se tak." Bůh ustanovuje zemi za prostřednici, matku zeleně a také živočichů (Gn 1,24). Proto nepotřebuje dávat své rozkazy každým rokem znovu: „Zazelenej se země zelení: bylinami, které se rozmnožují semeny, a ovocným stromovím rozmanitého druhu, které na zemi ponese plody se semeny..." (Gn 1,11), živým tvorům je dáno, aby se plodili a množili (Gn 1,22-25). Bưh tedy zařizuje tento svět tak, aby se bez jeho rozkazů stvoření udržovalo samo.

Spornou ve světle dnešních souvislostí se stává výzva: „At lidé panují [...] nad celou zemí..." (Gn 1,26). Předně to bylo vyřčeno ante lapsum, dokud člověk žil z Pramene a Dárce života a dokud neuvěřil svůdci, který lidi ujistil: „....budete jako Bůh znát dobré i zlé..." (Gn 3,5). 
Úcta ke Stvořiteli jako jedinému vlastníku země (Ž 24,1) vylučuje mandát k ničení stvořitelského díla. Jen člověku, který jedná v souladu s úctou ke Stvořiteli a s respektem ke stvoření, dává Bůh požehnání: "Bůh nám dává svoje požehnání. Necht' se ho bojí všechny dálavy země!" (Ž 57,7$)$. Bủh odpočinul dne sedmého, přestal konat a svět se přitom nezhroutil: "Sedmého dne dokončil Bưh své dílo, které konal; sedmého dne přestal konat veškeré své dílo..." (Gn 2,1-3). Člověku pak nakonec byla ponechána svoboda, aby jednal v souladu s Boží vưlí - nebo i proti ní.

Bible ovšem přece jen obsahuje jeden velmi instruktivní kánon o udržitelném rozvoji. Je jím příběh o potopě. Z př́kazu Božího je to člověk, který je vyzván, aby zachoval stvoření, navzdory hněvu Stvořitele. "A ze všeho, co je živé, ze všeho tvorstva, uvedeš vždy po páru do archy, aby s tebou zưstali naživu..." (G 6,19). Nemá smysl spekulovat proč není řeč o zeleni - vždyt' holubice přináší po potopě olivovou snítku jako důkaz vracející se zeleně (G 8,11).

Pro člověka nejdůležitější z hlediska potřeby nově chápat své poslání, jež má vést k udržitelnému rozvoji, je podobenství o boháči a stodolách a o zabezpečení života, jak čteme v evangeliu podle Lukáše. „A řekl jim: ,Mějte se na pozoru před každou chamtivostí, nebot' i když člověk má nadbytek, není jeho život zajištěn tím, co má..." (L 12,15- 21).

"A neshánějte se, co budete jíst a co pít, a netrapte se tím. Po všem tom se shánějí lidé tohoto světa. Váš Otec přece ví, co potřebujete. Vy však hledejte jeho království a to ostatní vám bude přidáno..." (L 12,29-31).

Od církví a člověka euroatlantické kultury se očekává ovšem víc takové zdrženlivosti - právě proto, že je to tato kultura, která zavádí lidstvo do slepé uličky "neudržitelnosti", a také proto, že její podíl na exploataci Země je rozhodující, protože největší. Myšlenky z eseje o askezi C. F. Weizsäckera Ize proto uvést do souvislosti $s$ tím, co bylo řečeno v tomto příspěvku: "Co máme z těchto poznatků vyvodit pro své jednání? Jak se zdá, jsou to dvě věci: na jedné straně, že bude pro budoucno nezbytné vytvářet nové podoby sebeovládání. Na druhé straně, že máme-li vyřešit hmotné potíže technické civilizace, nesmíme čekat, až se prosadí demokratickou cestou. [...] Jednou ze základních zkušeností askeze je to, že právě práce jedince na sobě samém proměňuje společnost svým uvědomělým vyzařováním. Tuto práci dnes konají jen ti jedinci, kteří jsou zasaženi bleskem vědomí svého podílení se na odpovědnosti za skutečný svět - tedy ne zrovna ti, kdo před ním utíkají. Přesnost uvědomování si věcí, jasnost myšlení, je jedním z nejdůležitějších výsledků intelektuálního sebeovládání; je jednou z morálních hodnot." (Weizsäcker, 1981).

Základem celkové změny pro církev i pro svět zůstává znovuobjevení Boží svatosti: „Nebudeš míti jiného boha mimo mne." (Ex 20,3).

\section{Literatura}

- ANNAN Kofi A, (2000). We the peoples: The role of the United Nations in the 21 st century. New York: UN.

- Braniš, M. (2001). Environmental Challenges: An Introduction to Environmental Law and Policy of the EU and OECD. Florida: Florida State University College of Law.

- Bultmann, R. (1957). History and Eschatology. Edinburgh: Edinburgh University Press.

- BYSTŘICKÝ, Jiří, MUCHA, Ivan, (2002). Simulace, systémy a kontingence. Pelhřimov: Vydavatelství 999. 
- COLBORN, Theo, MYERS, John Peterson, DUMANOSKI, Dianne, (1996). Our Stolen Future: Are We Threatening Our Own Fertility, Intelligence, and Survival?-A Scientific Detective Story. East Rutherford: Penguin Putnam Inc.

- Com, (1999). Europe's environment : What directions for the future?. Brussels: Commission of the European Communities.

- CONNELlY, James, SMITH, Graham, . Politics and the environment : From theory to practice. London: Graham.

- Eorg, (2002). Eurobarometer: The attitudes of Europeans towards the environment. Brussels: Directorate-General Press and Communication. Retrieved from http://ec.europa.eu/public_opinion/archives/ebs/ebs_180_en.pdf

- Europa : Publications Office. [cit. 2007-03-25]. Dokumenty EU. . . Retrieved from http://publications.europa.eu/index_en.html

- Global Economic Prospects and the Developing Countries (2000). Washington (DC): World Bank.

- Mezřický, (Václav) (ed.), . Globalizace. Praha: Portál.

- Grober, U. (2002). Denken wie ein Berg. Die Zeit 22.8.2002, Jahrg. 57, N. 35,

- Huizinga, J. (1958). Homo ludens : Vom Ursprung der Kultur im Spiel. Reinbek: Rowohlt.

- Jonas, H. (1984). Das Prinzip Verantwortung: Versuch einer Ethik für die technologische Zivilisation. Neuauflage als Suhrkamp Taschenbuch.. Franfurkt/M.

- Kaplan, R. D. (2003). Přicházející anarchie Praha. Praha: Pavel Mervart.

- Keller, J. (2000). Budoucnost otevrených obětí. Praha: Nepublikovaný text pro Křest'anskou akademii.

- Kincl, J., \& URFUS, Valentin., . Rímské právo. Praha: Panorama.

- Kišš, I. (2002) Význam myšlienky svätosti Zeme pre ekologickú etiku. In Náboženstvo - životné prostredie - hodnoty pre udržitelnú budúcnot': Zsborník z konferenie. Bratislava : Spoločnost' pre trvalo udržatel 'ný život. .

- Kosz, M. (1994). Friends of the Earth (FOE). Wien/Nestelbach.

- Kružíková, E. (1997). Ekologická politika a právo životního prostředí. Praha: Nakl. a vyd. litomyšlského semináře.

- Lorenz, K. (1997). Odumírání lidskosti. Praha: Mladá fronta.

- Mezřický, V. et al., (2001). Environmental Challenges: An Introduction to Environmental Law and Policy of the EU and OECD. Florida.

- Mezřický, V. (2005). Environmentální politika a udržitelný rozvoj. Praha: Portál. 
- Moldan, B. (1983). Koloběh hmoty v př́írodě. Praha: Academia.

- OECD Environmental Outlook (2001). Paris: OECD.

- Ophuls, W. (1997). Requiem for Modern Politics: The Tragedy of the Enlightenment and the Challenge of the New Millennium. Boulder (CO): Westview Press.

- ORTEGA Y GASSET, José., (1993). Vzpoura davů. Praha: Naše vojsko.

- Rees, M. (2003). Our Final Century? : Will the Human Race Survive the Twenty-first Century. Portsmouth: William Heinemann.

- Strupe, U. (1998). Einführung in das Alte Testament. Stuttgart: Verlag Katholisches Bibelwerk.

- Sustainable Germany : A contribution to sustainable Global development (1995). Wuppertal: Wuppertal Institute for Climate, Environment and Energy (WI).

- Světová komise pro životní prostředí a rozvoj, (1991). Naše společná budoucnost. Praha: Academia.

- SzÖlÖs, J. (2001). Křest'anství a ekologie. Bratislava: Společnost pro trvale udržitelný život.

- Šrobár, . (2002) Krest'anstvo a životné prostredie. In Náboženstvo - životé prostredie hodnoty pre udržatel'nú budúcnost': Sborník z konferenie ( $\mathrm{p}$. 105). : Společnost pre trvalo udržatel' ný život.

- Tischner, J. (1992). Krize moderního myšlení. : Filosofický ústav ČSAV. In Castelgandolfo-Gespräche 1985 : Über die Krise. Wien : Institut für Wissenschaften vom Menschen, 1986.

- Vernardskij, V. I. (1944). . Uspěchy sovremennoi biologii, XVIII(2),

- WACKERNAGEL, Mathis, REES, Williams E., (1995). Our Ecological Footprint : Reducing Human Impact on the Earth. Gabriola Island (BC): New Society Publishers.

- WeizsÄcker, C. F. (1992) Zpětný pohled na debatu. In Pojem krize v dnešním myšlení. Praha: Filosofický ústav ČSAV.

- World Values Survey website (WVS), (2006). World Values Survey 1999-2001. . Retrieved from http://www.worldvaluessurvey.org/services/index.html

\section{Poznámka}

Autor příspěvku si nepřeje zveřejnění textu recenzních posudků. 
Časopis Envigogika vydává Centrum pro otázky životního prostředí UK. Vývoj časopisu je podpořen projektem OP VK Mezioborová sít udržitelného rozvoje.

Více najdete na internetových stránkách projektu mosur.czp.cuni.cz
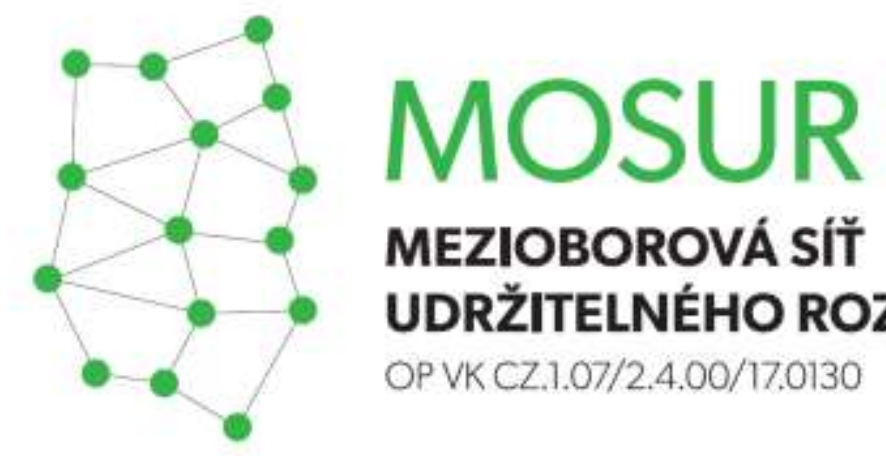

\section{MEZIOBOROVÁ SÍT} UDRŽITELNÉHO ROZVOJE

OP VK CZ.1.07/2.4.00/17.0130
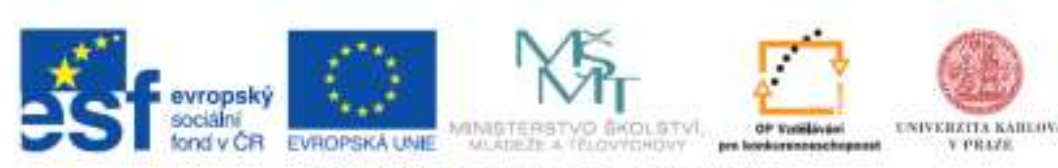

INVESTICE DO ROZVOUE VZDELAVANI 